\title{
Investigation typhoon induced storm surge and high wave in Vietnam using coupled Delft3d-FLOW - WAVE models combined with weather research forecast (WRF) output wind field
}

\author{
Le Tuan Anh ${ }^{*}$, Dang Hoang Anh, Mai Thi Yen Linh, Nguyen Danh Thao
}

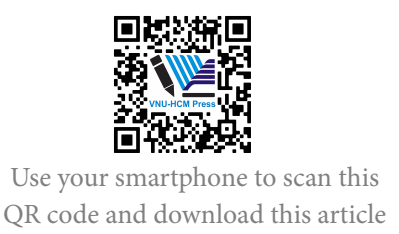

Department of Port and Coastal Engineering, Faculty of Civil Engineering, Ho Chi Minh City University of Technology, VNU-HCM, Vietnam

Correspondence

Le Tuan Anh, Department of Port and Coastal Engineering, Faculty of Civil Engineering, Ho Chi Minh City University of Technology, VNU-HCM, Vietnam

Email: tuananh131188@hcmut.edu.vn

History

- Received: 30-9-2020

- Accepted: 07-01-2021

- Published: 15-02-2021

DOI : 10.32508/stdjet.v4i1.774

\section{Check for updates}

Copyright

(c) VNU-HCM Press. This is an openaccess article distributed under the terms of the Creative Commons Attribution 4.0 International license.

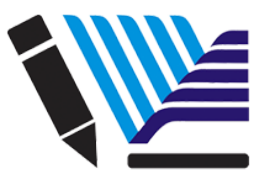

VNU-HCM Press

\begin{abstract}
Introduction: Typhoon-induced disasters including storm surge and high wave are obvious threats to coastal areas in Vietnam. Thus, many researchers have paid their attention to this issue. The approaching methods are varied, including statistical methods and also numerical methods. This study suggests the coupled models Delft3D-FLOW and WAVE, using the meteorological output data from the Weather Research Forecast (WRF) for investigating the typhoon induced disasters in the coastal areas in Viet Nam. Method: WRF is run in multiple domains with different grid resolutions simultaneously and there is an interaction between them to reproduce the wind field during the typhoon events. Delft3D-FLOW is coupled with Delft3D-WAVE (SWAN) through a dynamic interaction, in which the FLOW module considers the received radiation stresses calculated by the wave module. On the other side, the updated water depth including the contribution of the storm surge will be used by the WAVE module. Both Delft3D-FLOW and Delft3D-WAVE models used wind fields from the WRF simulation output as the meteorological input data. The total surge level includes the storm surge, wave-induced setup and the tidal level. Results: The case of extreme weather event Typhoon Kaemi (2000) was used to validate the wind field and the wave height. The calibration process of the the storm surge level was based on the observed data during Typhoon Xangsane (2006), while Typhoon Durian (2006) were used to validate the coupled models. The comparisons show the good agreement between simulated results and observed data, especially in terms of the peak water level and highest significant wave height, which mainly governed by the typhoon wind field. The simulated results reveal that the surge height durring Typhoon Durrian period along its path was ranged from 1.2 to more than $1.4 \mathrm{~m}$, which can be considered to pose the greatest risk to low-lying coastal areas of the Mekong Delta. Conclusion: The suggested coupled models can be used to investigate the impact of typhoon induced disasters. ${ }^{1-26} 27-38$ 39-63

Key words: typhoon, storm surge, wind wave, Vietnam, WRF, Delft3D
\end{abstract}

\section{INTRODUCTION}

Typhoons are one of the most hazardous extreme meteorological phenomena that most of the coastal countries in the world have to cope with it. Strong wind and heavy rain from typhoons can cause major disasters. During a typhoon, the seawater level is increased abnormally by the effect of strong winds and sea level pressure drop near the center. This phenomenon is called the combination of inverse barometric effects and air-sea interactions. It generates storm surges, which a type of long wave with a characteristic of occurrence time from several hours up to one day and a wavelength approximately between 150 and $800 \mathrm{~km}^{1}$. Furthermore, under the typhoon condition, the dominant process of momentum transferring from the atmosphere into the ocean also results in waves. This wave field introduces radiation stress gradients, which further influence seawater and raise its level.

Storm surge is one of the most catastrophic disasters causing extensive physical impact. For example, more than 1000 fatalities were recorded during Hurricane Katrina in 2005 in Louisiana and 200 in Mississippi, which was the consequence of the 10-meter storm surge occurring along the Mississippi coastline ${ }^{2}$. In the inner-most part of Layte Gulf in the Philippines, a $6 \mathrm{~m}$ storm surge ${ }^{3}$ caused by the catastrophic Typhoon Haiyan (2013) resulted in enormous economic damage, with more than 6000 individuals were reported dead $^{4}$. Recently, the storm surge caused by Typhoon Hato (2017) reached up to 2.5-m in Macau and significantly impacted Macau's economy ${ }^{5}$, fortunately, in this case, the number of the casualty was relatively low. Additionally, typhoon induced high waves also have the potential to cause severe physical impact. The maximum hindcast wave heights due to the passage of Haiyan through eastern Samar was up to 20 
$\mathrm{m}^{6}$.

Vietnam is a country that is frequently hit or affected by the typhoon, typhoon related events occupied $80 \%$ of the number of disasters affecting Vietnam ${ }^{7}$. The peak occurrence of typhoon landfalls is different in each region. For the central part, the peak time is normally during October, whereas, in the southern part, it is November. According to statistical data, approximately 786 typhoons that approached or affected Vietnam during the twentieth century were recorded. These storms mainly made landfall at the coastal provinces in the north and the center of Vietnam ${ }^{8}$. Recently, the Ministry of Natural Resources and Environment of Vietnam (MONRE) pointed out that the number of high-intensity typhoons affecting Vietnam had increased due to global climate change. It has been identified that there is a trend that typhoon tracks tend to move southward and the typhoon season is lasting long ${ }^{9,10}$. Summing several Vietnamese reports and articles, MONRE also declared that the higher number of typhoons in the context of climate change could lead to growing concerns over the threat posed by typhoons. According to the statistical data, storm surge has also been identified to cause severe damage in Vietnam. For example, Typhoon Kelly in 1981 made landfall in Nghe An, Central Vietnam, caused storm surges up to $3.2 \mathrm{~m}$; water level elevation during Typhoon Andy, 1985 in Quang Binh, Central Vietnam, was $1.7 \mathrm{~m}$. In 1986, in Thai Binh, North Vietnam, a storm surge induced by Typhoon Wayne was recorded as high as $2.3 \mathrm{~m}^{11}$.

Due to the severe consequences of typhoon related disasters, including storm surge and high wave, many researchers had paid attention to investigating historical events. In the past, they often used the numerical model to simulate a single phenomenon such as the tide or wave, or storm surge component of a typhoon. Kim, $2010^{12}$ and Islam et. al., 2020a ${ }^{13}$, suggested that storm surge could not be represented comprehensively by using only the wind and pressure field of a typhoon for open coasts. An advanced way to simulate storm surge requires the coupling of different models, including meteorological, hydrodynamic, and wind-wave model. For example, Mastenbroek, $1993^{14}$ and Zhange $\mathrm{Li}, 1997^{15}$ coupled storm surge and wind-wave model. However, the wave model WAM that they used did not consider the shoaling and diffraction effect, including a breaking wave. Recently, Xie et. al. $2008^{16}$ investigated the impact of radian stress on the coastal flooding during Typhoon Hugo (1989) by using the POM model developed by Princeton University and SWAN model.
At the same time, the issues regarding storm surge have also been investigated by many Vietnamese researchers. Vu Nhu Hoan, $1988^{17}$ used statistical and graphical methods to investigate the storm surge at the interesting locations. Pham Van Ninh, $1992^{18}$ developed 2-D storm surge model within the project UNDP VIE/87/020. However, this model was calibrated based on the data from the Sixties. Nguyen $V u$ Thang, $1999^{19}$ estimated the surge level at the coastal area in Hai Phong based on the finite element method. He introduced the procedure to generate the storm surge forecasting map. Bui Xuan Thong in $2000^{20}$ applied the numerical model using the nested grids to reproduce the storm surge in the Vietnam coastal area. In this way, he was successful in overcoming the limitation of the computational resources and obtain accurate results. Another study was implemented by Nguyen Xuan Hien, $2012^{21}$ implemented the empirical equation to estimate the surge level under the effect of wave in the coastal zone in Hai Phong. The present study suggests the coupled models, which considered the interaction between storm surge and wind-wave, using for investigating the typhoon induced disasters in the coastal areas. The paper has the following structure of two parts. First, we outline the way how meteorological data was reproduced by using the WRF model. The second is focusing on applying the reproduced wind field into the coupled storm surge - wave model. The significant typhoon events in Central and Southern Vietnam were chosen as case studies.

\section{METHODOLOGY}

Numerical analysis is an effective way to forecast the typhoon related disasters according to the expected spatial and temporal distribution. The storm surge risk and also high wave during the typhoon period have already been investigated by many researchers in developed countries such as America, Japan. To accurately reproduce the storm surge and high wave, it is necessary to consider three main components, including how to generate the meteorological data, what type of storm surge and wind-wave model are suitable, and also how to couple these models.

Several researchers focus on numerical weather prediction (NWP) models to overcome the limitation of synoptic and statistical methods. The ultimate goal of these models is to reproduce wind-field as accurately as possible so that the intensity of typhoons and related extreme atmospheric phenomena could be exactly evaluated $^{22}$. One of the famous mesoscale meteorological models basing on the joint development 
between The National Center for Atmospheric Research (NCAR) and the National Center for Environmental Prediction (NCEP) is The Weather Research and Forecasting (WRF) model ${ }^{23}$. The WRF model can be simulated at different scales for both global and regional climate, as well as the atmospheric motion. Besides, air quality can also be evaluated by WRF. WRF is also can be used for typhoon simulation and reproduce the interaction between air-sea, that why it is widely used and has become the most common mesoscale atmospheric model. Currently, there are two different dynamic frameworks of WRF including ARW (the advanced research WRF) and NMM (the non-hydrostatic mesoscale model), maintained and developed by the NCAR and NCEP, respectively. The ARW-WRF ${ }^{24}$, which is one of the most popular models using to predict typhoons due to its stable performance, is used in this paper. Mori, $2014^{25}$ simulated Typhoon Haiyan, 2013 mainly based on the results from WRF, and the results show that WRF has the potential to reproduce the wind field during typhoon Haiyan reasonably accurate. Then, they used the output of the WRF as the boundary conditions of the ocean-wave coupled model.

When using WRF, two aspects need to be paid attention to is the changes in the track and intensity of the typhoon. The interaction of multi-scale meteorological systems such as the interaction between the occurrence and development of the subgrid process and the large-scale background environment ${ }^{26-28}$ resulted in those issues. In another word, the simulation results depend on the use of different grid resolutions in typhoon numerical simulations. Usually, because of the limitation of the integral calculation of the numerical model, the description of the atmospheric motion close to the grid or either the sub-grid scales will be less accurate. Generally, to overcome this issue, the parameterization of various physical processes of these sub-grid scales including radiation, cumulus convection, boundary layer... need to be considered ${ }^{26,29,30}$.

In terms of the storm surge model, many studies were conducted a long time ago. Jelesnianski implemented the simple numerical model, in which he ignored the friction and non-linear components to represent the storm surge. The result showed that the highest water level appeared on the right side of the affected area and simultaneously with the typhoon hitting land ${ }^{31}$. One of the well-known storm surge models is SLOSH model developed by NOOA (National Oceanic and Atmospheric Administration) and widely used to simulate the coastal flooding caused by typhoons. Threr is a simplified parametric wind model integrated in the SLOSH model. The SLOSH is a 2-D explicit, Finite Difference (FD) model formulated on a semi-staggered Arakawa B-grid ${ }^{32}$. SLOSH can be used for wetting and drying simulation as well as it is able to parameterize sub-grid scale features including 1-D channel flow with contractions and expansions, overtopping flow through the vertical obstructions (levees, roads...), and friction drag increasing due to the vegetable. However, as other numerical models, SLOSH does have limitations. First, the SLOSH grid shows the limitation in size especially at the coastal shelf surrounding the study area. Second, the lack of knowledge of set-up at the open boundary leads to the less accuracy of boundary conditions specification during storm surge events, this limitation also makes the dynamic coupling to larger basins impossible. SLOSH also does not include precipitation, river flow, and wind-driven waves.

Furthermore, several other storm surge modeling systems have been widely used for predicting the impact of typhoons (inundation in coastal areas due to tropical storms), covering a range of numerical methods, model domains, forcing and boundary conditions, and purposes. Standard other models include the Advanced Circulation (ADCIRC) model, Primitive Equation Community Ocean Model (FVCOM), the Princeton Ocean Model (POM), Curvilinear-Grid Hydrodynamics 3D Model-Storm Surge Modeling System (CH3D-SSMS), the Finite-Volume. While all these models are used for the same purpose, each model has its pros and cons and more well-suited for a particular application.

For the wave modeling, numerical models such as Wave Action Model (WAM) ${ }^{33}$, WAVEWATCH III $(\text { WW3 })^{34}$, MIKE21 Spectral Waves ${ }^{35}$, Simulating Waves Nearshore (SWAN) ${ }^{36}$ are commonly used $^{37-39}$. WAM and WW3 are mainly used for global and regional scale applications, whereas SWAN is suitable for nearshore modeling. There is the fact that the wave models strongly depend on wind field variations, thus the quality and the accuracy of the wind fields also affect the quality of numerical wave hindcast ${ }^{40,41}$.

When simulating the storm surge and wave by the numerical model, it is noticed that the interaction between storm surges and waves is a two-way interaction. Wave height is controlled by wave breaking. In other word, waves height also depend on the local water depth. Thus, the contribution of increasing water caused by a storm surge, wave set-up, and tide to the total water depth affects wave height. On the other hand, the presence of waves generates radiation stresses, which will increase the peak water level 
through the phenomenon named wave set-up ${ }^{42,43}$. The contribution of wave set-up to total increasing water level was confirmed by Xie et al., $2008^{16}$ when they investigated the inundation in Charleston Harbor during the 1989 Hurricane Hugo by applying the Princeton Ocean Model and Simulating Waves Nearshore (SWAN) model. Funakoshi et al., $2008^{44}$ pointed out that the contribution of rising ware causing by wave-induced radiation stresses reached up to $10-15 \%$ of the total increasing water levels by coupling ADCIRC (Advanced Circulation Model) and SWAN for the case study of Hurricane Floyd in 1999. Chen et al., $2008^{45}$ researched Hurricane Katrina in 2005 and concluded that the local wind forcing played the main role in the generation of storm surge when it was responsible for $80 \%$ of the maximum surge, while, the remaining $20 \%$ was caused by the combined effects of tides, surface waves, and offshore.

In this study, the Delft3D-WAVE module, which uses the SWAN spectral wave model is used. The thirdgeneration wave model SWAN is suitable for simulating the random, short-crested, and wind-generated waves in coastal regions and inland waters ${ }^{36}$. The governing equation of the SWAN model is based on the action balance equation with sources and sinks (Equation 1). The hydrodynamics module Delft3DFLOW is used to investigate the typhoon-induced water level. FLOW is based on the assumptions of shallow water and hydrostatic to solves the continuity (Equation 2) and Navier-Stokes equations (Equation $3,4)$ for an incompressible fluid. The Delft3D FLOW module can be applied to three-dimensional phenomena. However, in cases of long waves such as storm surges $^{46}$, tsunamis, and tidal propagation ${ }^{47}$ a twodimensional horizontal grid is commonly used.

In Equation 1, the first term in the left-hand side takes the time-depending local rate of change of action density into account, while the second and third terms represent the propagation of action in geographical space (with propagation velocities $c_{x}$ and $c_{y}$ in $x$ - and $y$-space, respectively). The fourth term represents the shifting of the relative frequency causing by the variations in depths and currents (with propagation velocity $c_{\sigma}$ in $\sigma$-space), while the last term is the depthinduced and current-induced refraction (with $c_{\theta}$ is propagation velocity in $\theta$-space). The above propagation speeds are based on the linear wave theory ${ }^{48-50}$. The term $S=S(\sigma ; \theta)$ at the right-hand side of Equation 1 is the source term in terms of energy density representing the effects of generation, dissipation, and non-linear wave-wave interactions.

$$
\begin{array}{r}
\frac{\partial}{\partial t} N+\frac{\partial}{\partial x} c_{x} N+\frac{\partial}{\partial y} c_{y} N+ \\
\frac{\partial}{\partial_{\sigma}} c_{\sigma} N+\frac{\partial}{\partial_{\theta}} c_{\theta} N=\frac{S}{\sigma}
\end{array}
$$

$$
\begin{aligned}
& \frac{\partial \xi}{\partial t}+\frac{1}{\sqrt{G \xi \xi} \sqrt{G \eta \eta}} \frac{\partial[(d+\zeta) U \sqrt{G \eta \eta}]}{\partial \xi} \\
& +\frac{1}{\sqrt{G \xi \xi} \sqrt{G \eta \eta}} \frac{\partial[(d+\zeta) U \sqrt{G \xi \xi}]}{\partial \eta}=Q \\
& \frac{\partial u}{\partial t}+\frac{u}{\sqrt{G_{\xi \xi}}} \frac{\partial u}{\partial \xi}+\frac{v}{\sqrt{G_{\xi \xi}}} \frac{\partial u}{\partial \eta}+ \\
& \frac{\varpi}{d+\zeta} \frac{\partial u}{\partial \sigma}-\frac{v^{2}}{\sqrt{G_{\xi \xi}} \sqrt{G_{\eta \eta}}} \frac{\partial \sqrt{G_{\eta \eta}}}{\partial \xi} \\
& +\frac{u v}{\sqrt{G_{\xi \xi}} \sqrt{G \eta \eta}} \frac{\partial \sqrt{G_{\xi \xi}}}{\partial \eta}-f v= \\
& -\frac{1}{\rho_{0} \sqrt{G_{\xi \xi}}} P_{\xi}+F_{\xi}+ \\
& \frac{1}{(d+\zeta)^{2}} \frac{\partial}{\partial \sigma}\left(v_{v} \frac{\partial u}{\partial \sigma}\right)+M_{\xi} \text {. } \\
& \frac{\partial v}{\partial t}+\frac{u}{\sqrt{G_{\xi \xi}}} \frac{\partial v}{\partial \xi}+\frac{v}{\sqrt{G_{\xi \xi}}} \frac{\partial v}{\partial \eta}+ \\
& \frac{\varpi}{d+\zeta} \frac{\partial v}{\partial \sigma}-\frac{u v}{\sqrt{G_{\xi \xi}} \sqrt{G_{\eta \eta}}} \frac{\partial \sqrt{G_{\eta \eta}}}{\partial \xi} \\
& +\frac{u^{2}}{\sqrt{G_{\xi \xi}} \sqrt{G \eta \eta}} \frac{\partial \sqrt{G_{\xi \xi}}}{\partial \eta}+f u= \\
& -\frac{1}{\rho_{0} \sqrt{G_{\eta \eta}}} P_{\eta}+F_{\eta}+ \\
& \frac{1}{(d+\zeta)^{2}} \frac{\partial}{\partial \sigma}\left(v_{v} \frac{\partial v}{\partial \sigma}\right)+M_{\eta} \text {. }
\end{aligned}
$$

In these equations, coefficients $\sqrt{G_{\xi \xi}} \sqrt{G \eta \eta}$ are used for the transformation from the curvilinear to rectangular coordinates, $Q$ is the global source ( $\operatorname{sink}$ ) per unit area, $v_{V}$ is the vertical eddy viscosity coefficient, $P_{\xi}$ and $P_{\eta}$ represent the pressure gradients. The forces $F_{\xi}$ and $F_{\eta}$ in the momentum equations represent the unbalance of horizontal Reynold's stresses. $M_{\xi}$ and $M_{\eta}$ represent the contributions due to external sources or sinks of momentum in $\xi$ and $\eta$ - direction (the external could be caused by hydraulic structures, discharge or withdrawal of water, wave stresses, etc.). The gradients of radiation stress from wave represents the input source terms in the momentum equations. Therefore, the obtained radiation stress will make the surge module be modified to include the effect.

Delft3D-FLOW is coupled with Delft3D-WAVE (SWAN) through a dynamic interaction, in which the FLOW module considers the received radiation stresses calculated by the wave module. On the other side, the updated water depth including the contribution of the storm surge will be used by the WAVE module. Current feedback was not 
considered in this study. In the coupled model, the FLOW module is expected to read wave data from the communication file at certain time points during the computation. The process names Online Delft3D-WAVE is selected to enable the coupling process between the Delft3D-FLOW computation and the Delft3D-WAVE (SWAN). This feature is called the Online-WAVE option. To clearly describe the coupling procedure, the diagram in Figure 1 is shown. In the 2-way coupled model, Delft3D-FLOW always runs first. The storm surge calculated by Delft3D-FLOW in the first time step is transferred to the common file (so-called, communication file). Accordingly, the wave module updates the water depth (the sum of still water depth and storm surge) using the latest communication file and starts calculating wave height and wave radiation stress. In the next round, the hydrodynamic module considers the effect of the radiation stresses calculated by the wave module. The varying radiation stresses induce changes in the mean surface elevation (wave set up). The new water level is then updated in Delft3D-FLOW in the next time step. Those cycles are iterated until the end of simulation time period.

\section{MODEL SETUP}

The simulation was implemented for the case of three typhoons including Typhoon Kaemi (2000) and Typhoon Xangsane (2006) made landfall in Da Nang area, Typhoon Durian (2006) made landfall at the Mekong Delta (Figure 2). The procedure of model simulation is described in Figure 1. Meteorological model WRF was used to reproduce the wind field, including wind speed and central pressure. There are three simulated domains in each WRF running: Domain 1 with a resolution of $30 \mathrm{~km} \times 30 \mathrm{~km}(73 \times 73$ grid points) cover the entire area of the East sea, Domain 2, with a resolution of $10 \mathrm{~km} \times 10 \mathrm{~km}$ ( $73 \times 73$ grid points) focusing on the offshore area in the Central Vietnam Domain D2-1 (for the case of Typhoon Kaemi and Typhoon Xangsane) and in Mekong delta (for Typhoon Durian)- Domain D2-2. Domain 3 with resolution $3.33 \mathrm{~km} \times 3.33 \mathrm{~km}$ (73x73 grid points), including D31 and D3-2 focusing on the coastal area around Da Nang and Ho Chi Minh City, respectively. In this study, the input meteorological data were taken from the National Centers for Environmental Prediction (NCEP). Then, the generation process of the initial atmospheric conditions for the WRF was done by the Global Forecast System (GFS). As mentioned above, in the WRF setting, several physical schemes need to be parameterized to overcome the problem that the less accuracy of the atmospheric motion close to the grid or the sub-grid scales due to the limitation of the integral calculation of the numerical model:

- The cumulus parameterization is responsible for the calculation of the effect of subgrid-scale convection on the grid-resolved thermodynamic variables.

- The planetary boundary layer (PBL) considers the phenomenon of transportation of eddy in the whole atmospheric column, which results in the vertical sub-grid-scale fluxes. The flux profile within the well-mixed boundary layer and the stable layer is also determined by the PBL schemes. In addition, the prediction of temperature, moisture (including clouds), and momentum tendencies in the horizontal plane in the entire atmospheric column are also provided by the PBL schemes ${ }^{23}$.

- The microphysics parameterizations (MP) explicitly handle water vapor, cloud, and precipitation processes. Furthermore, MP is also accounted for the processes of melting of snow, graupel and cloud ice hydrometeors, suppression of falling rain by evaporation.

- The land-surface models (LSMs): the processes including the thermal and moisture fluxes in multiple layers of the soil; canopy effects and surface snow-cover are considered by LSMs. These models use information from other schemes to run, such as using atmospheric information from the surface layer scheme, radiative forcing from the radiation scheme, and precipitation forcing from the microphysics and convective schemes. As the results, the LSMs output includes heat fluxes and moisture over the land points and sea-ice points, that used as the lower boundary condition fluxes for the PBL schemes $^{23}$.

- Short wave radiation (SWR) schemes handle the atmospheric heating as the consequence of radiation flux from the Sun. The SWR scheme is also responsible for the calculation of the process of absorption, reflection, and scattering in the atmosphere as well as from the surface.

- The long wave radiation (LWR): the process of absorption (emission) of infrared (thermal) radiation by gases and surfaces are the main objects of LWR.

WRF version 3.9.1 was used in this study. The twoway nesting scheme was set up. In others words, there are 3 domains with different grid resolutions run simultaneously in WRF model and the communication 


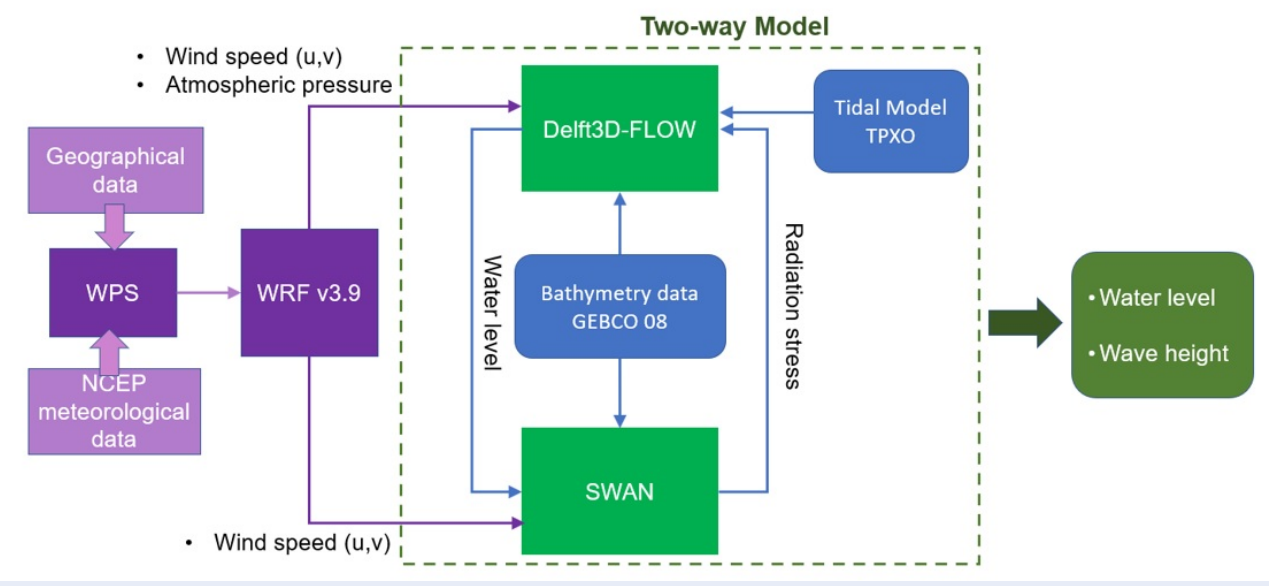

Figure 1: The procedure of coupling models

Table 1: WRF configuration

\begin{tabular}{|c|c|}
\hline \multicolumn{2}{|l|}{ Simulation time (all domains) } \\
\hline Typhoon Kaemi (2000) & 0:00 UTC 19/08/2000- 0:00 UTC 24/08/2000 \\
\hline Typhoon Xangsane (2006) & 0:00 UTC 25/09/2006- 0:00 UTC 02/10/2006 \\
\hline Typhoon Durian (2006) & 0:00 UTC 01/12/2006- 0:00 UTC 06/12/2006 \\
\hline \multicolumn{2}{|l|}{ Grid resolutions } \\
\hline (D1; D2-1; D3-1) & $30.0 ; 10.0 ; 3.3 \mathrm{~km}$ \\
\hline \multirow[t]{2}{*}{ (D1; D2-2; D3-2) } & $30.0 ; 10.0 ; 3.3 \mathrm{~km}$ \\
\hline & $50 \mathrm{hPa}$ \\
\hline Pressure top of the model & 27 \\
\hline Number of Vertical layers & 2-way nesting ( 3 domains) \\
\hline Nesting scheme & Revised MM5 surface layer scheme $e^{51-55}$ \\
\hline Surface layer & WRF Single-Moment 6-class scheme (WSM6) ${ }^{56}$ \\
\hline $\begin{array}{l}\text { Micro physics } \\
\text { Land surface option }\end{array}$ & $\begin{array}{l}\text { Noah land surface model }{ }^{57} \text { : unified NCEP/NCAR/AFWA } \\
\text { scheme with soil temperature and moisture in four layers. }\end{array}$ \\
\hline Planetary boundary condition & Yonsei University scheme (YSU) ${ }^{58}$ \\
\hline Map projection & Lambert conformal \\
\hline Bathymetry data & USGS \\
\hline Meteorological data & NCEP FNL Operational Global Analys \\
\hline Meteorological data resolution & $1^{o} \times 1^{o}$ \\
\hline
\end{tabular}


between them is enable: It means after the coarser domain run, the boundary values from it will be provided for the nest, then the nest run its calculation and feeds back to the coarser domain (Figure 2). By using the World Programming System (WPS), which is the WRF pre-processing software, the computational grid was created. The grids parameter (size, resolution), the simulation time, and also the schemes are presented in Table 1. The simulation run-time was chosen from 5-7 days in order to cover the entire occurrence period of the typhoon events. The atmospheric input data was generated from the NCEP FNL Operational Global Analysis (NCEP FNL 2000) 6-hourly GRIB-formatted meteorological data with 1-degree grids.

The hydrodynamic and wave model run in the same domains as the WRF model, but with different resolution. All three domains D1, D2-1/ D2-2, D3-1/D3-1 are used for the Delft3D-FLOW simulation. The domain D1 with the resolution of 0.2 degrees is the computational domain for the astronomical tide model, thus it runs first. The boundary conditions (tidal forcing) are derived from the Global Inverse Tide Model (TPXO 8.2). The providing tides are composed of amplitude and phase, including eight primaries (M2, $\mathrm{S} 2, \mathrm{~N} 2, \mathrm{~K} 2, \mathrm{~K} 1, \mathrm{O} 1, \mathrm{P} 1, \mathrm{Q} 1$ ), two long periods (Mf, $\mathrm{Mm}$ ), and 3 non-linear (M4, MS4, MN4) harmonic constituents. The tide simulation is run for 30 days to provide a tidal level variation. It is noticed that the later and finer resolution domains were nested in and used water level from the larger domains as the boundary data. The domains D2-1 and D2-2 with the same size as the domains of WRF model, but with a resolution of 0.1 degrees, received the water level along its boundary from the domain D1 and then transmit the tide level to the smaller nested domain inside, D3-1 and D3-2 respectively. The storm surge simulation was run in the domains D3-1 and D3-2 with a resolution of 0.01 degrees. Wave simulation using Delft3D-WAVE (SWAN) only used domains D31 and D3-2 as the computational domain and coupled with the hydrodynamic model through a twoway coupled method, as mentioned above (Figure 3). The computational period of Delft3D-FLOW model was as same as period of the WAVE model. The timesteps as short as 0.1 minutes was chosen for the stable computation purpose. The coupling timestep between the two models was every 20 minutes. The simulated period for the coupled model is the same as the calculation period using for the WRF model (Table 1). Both Delft3D-FLOW and Delft3D-WAVE model simulations used the bathymetric data retrieved from the GEBCO 08. Both models were forced by the wind fields from the corresponding WRF simulation results (domain D3-1 and D3-2). The output data from WRF contain many variables, such as sea-level pressure and $\mathrm{x}$-, $\mathrm{y}$ - direction components of wind.

Among the physical processes available in the Delft3D-WAVE module, the depth-induced wave breaking, bottom friction effect, wind-wave growth, white-capping effect, non-linear triad, and quadruplet interactions were enable. The wave spectral parameters were set as default: the frequencies range between $0.05 \mathrm{~Hz}$ and $1 \mathrm{~Hz}$, divided into 24 bins, while the wave directions were divided into 36 bins separated by $10^{\circ}$ for each bin.

\section{MODEL CALIBRATION AND VALIDATION}

In the hydrodynamic model Delft3D-FLOW, there are two main parameters that need to be considered to calibrate models: wind drag coefficient and the roughness parameter. In this paper, the authors referred to the common publications that also focused on similar interesting areas to choose the suitable wind drag coefficient and roughness parameter (Manning coefficient) ${ }^{59-61}$.

Due to the lack of real wave data, thus the wind speed data and wave parameters are only compared with data at Tien Sa lighthouse and the nearshore location (named Wave observation), respectively, which referred to Nguyen Ngoc Tran et. al., $2003^{61}$ (Figure 4) for checking the accuracy. The simulated water level is calibrated by comparing with the data of water level at Son Tra gauge station (Da Nang), which was referred to the research of Vu Hai Dang et al., $2017^{60}$. The hourly measured water level at Vung Tau gauge station was used to validate the simulation of water level during Typhoon Durian, 2006.

\section{RESULTS}

The peak typhoon season in Central Vietnam often starts from August until October. Typhoon Kaemi, which was chosen for the validation wave model in this study. Five typhoons had formed on the South China Sea before Kaemi. It is noticed that the total time from creation to the landing of this typhoon was relatively short, just only 2 days. The maximum 10minute average wind speed during Typhoon Kaemi (2000) was estimated at $20 \mathrm{~m} / \mathrm{s}$, while the highest instantaneous wind speed reached $26 \mathrm{~m} / \mathrm{s}$ occurring at 5.50 and 9.25 on 22 August (local time -UTC+7) measured at Tien Sa Lighthouse. The maximum 10minute average wind speed was $21 \mathrm{~m} / \mathrm{s}$ recorded at 


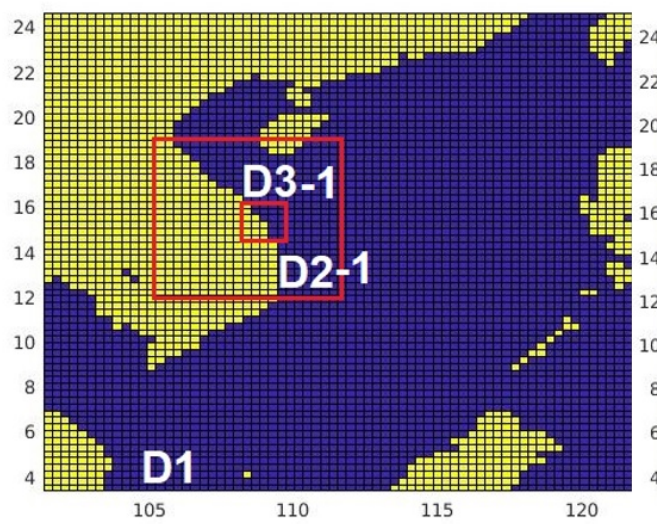

a)

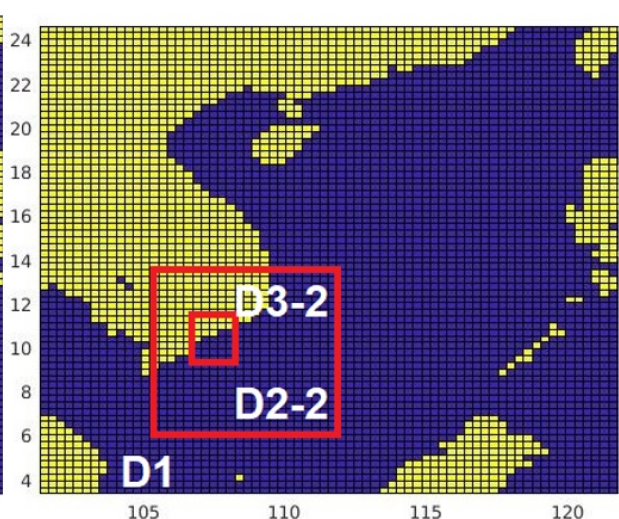

b)

Figure 2: WRF Calculation domains a) For Typhoon Kaemi (2000) and typhoon Xangsane (2006); b) For Typhoon Durian (2006)

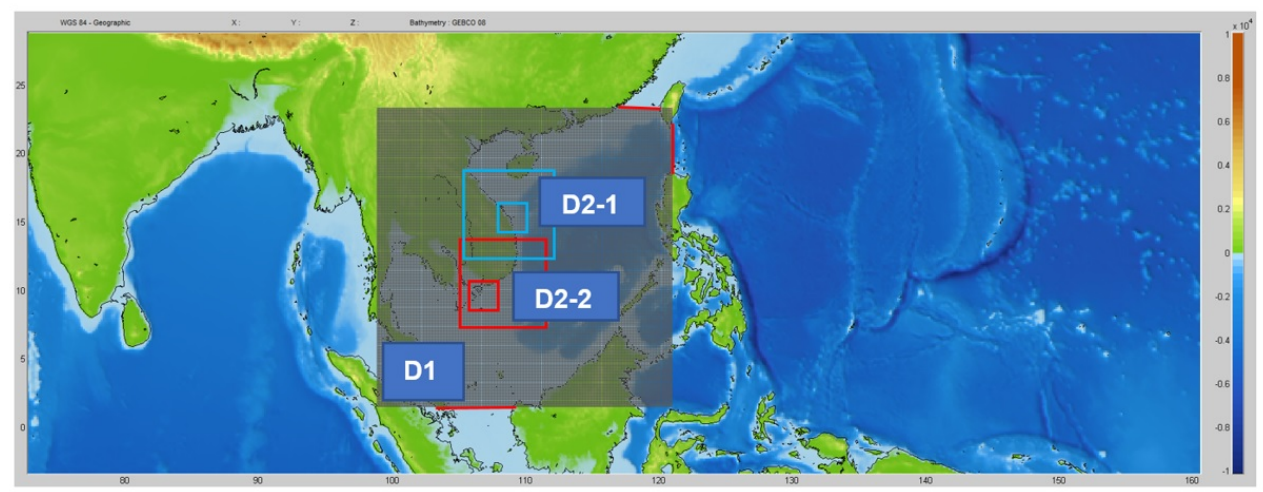

Figure 3: Computational domains for Delft3D models

5.50 on 22 August (local time -UTC+7) ${ }^{61}$. The simulated wind speed from the WRF model in the case of Typhoon Kaemi is shown in Figure 5. The comparison with measured data showed a good agreement, especially in terms of the maximum wind speed at the time mentioned above from the published article. In another word, the reproduced wind filed from the WRF model is reliable enough to use as the input data for the hydrodynamic and wave model.

The time series of the simulated results compared with the record in terms of wave heights are shown in Figure 6. It can be seen that from the observed data, there are two peaks, one high and one low. The values reproduced by the models also show two peaks at the corresponding time. However, the model results appear to be underestimated compared with the observed data before the typhoon hit the land. It can be partially explained by the limitation of swell simulation, which propagates before the occurrence of locally generated wind waves. The wind-generated wave in the near shore zone could be reproduced by running the WAVE model within the computational domain D3-1, but this size is not sufficient for simulating the swell propagation that travelling from the offshore. Therefore, the model's ability regarding the simulation of maximum wave height during the typhoon landfall period is the main thing we concentrate. In this sense, the model is accurate when the simulated peak fits well with the real value, around $5 \mathrm{~m}$. After the typhoon made landfall, the wave was mainly governed by the typhoon. Thus the patterns for wind speed can be visually estimated as quite similar. 

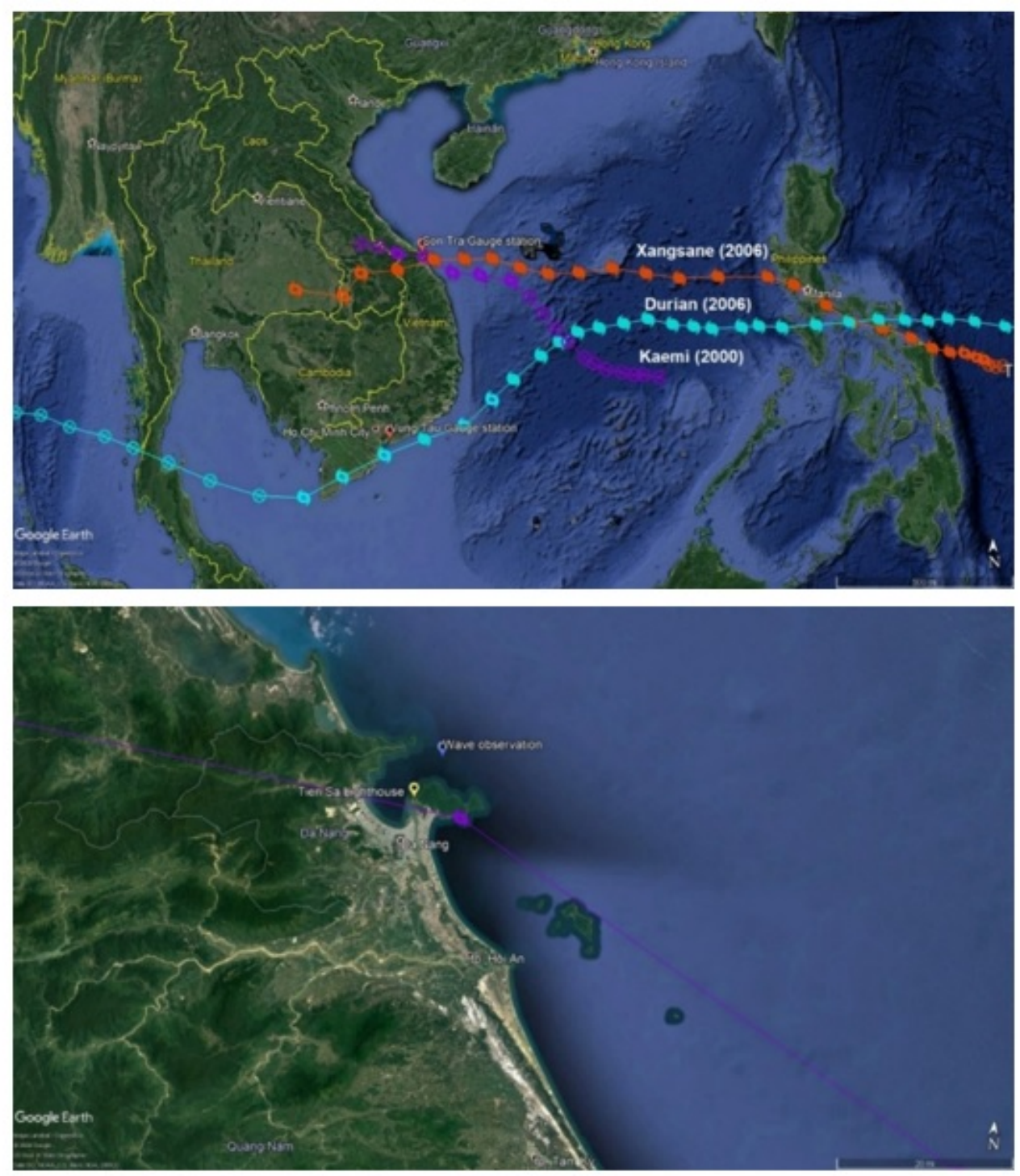

Figure 4: Gauge stations, Meteo station, and wave observed station

To validate the simulated water level caused by the typhoon, the cases of typhoon Xangsane (2006) and Typhoon Durian (2006) were used. According to the Japan Meteorological Agency (JMA), a tropical depression formed on September 25 on the East side of the Philippines. After that, the system quickly strengthened and moved toward the west direction, and both the JMA and the JTWC announced it reached the tropical storm intensity on September 26. Then, Xangsane was used as her international name. After passing over Manila, it approached the South China Sea and continued moving westward. The typhoon hit central Vietnam on September 30, and by Sunday, October 1, had passed through southern Laos and into Thailand as a tropical depression. It was reported that 13 people were killed from storm-related injuries due to this typhoon in Vietnam. According to JMA, the central pressure reached the value of $965 \mathrm{hPa}$ before making landfall and the sustainable wind speed was around 70 knots $(35 \mathrm{~m} / \mathrm{s})$.

The wind field of Typhoon Xangsane was reproduced by the WRF model, using the same computational mesh as Typhoon Kaemi (2000). The simulation period was 7 days, cover all the period since Xangsane started coming into the East Sea. The Delft3D-FLOW coupled with Delft3D-WAVE (SWAN) using the output from WRF as input and considered the tidal effect to simulated the storm surge caused by Typhoon 

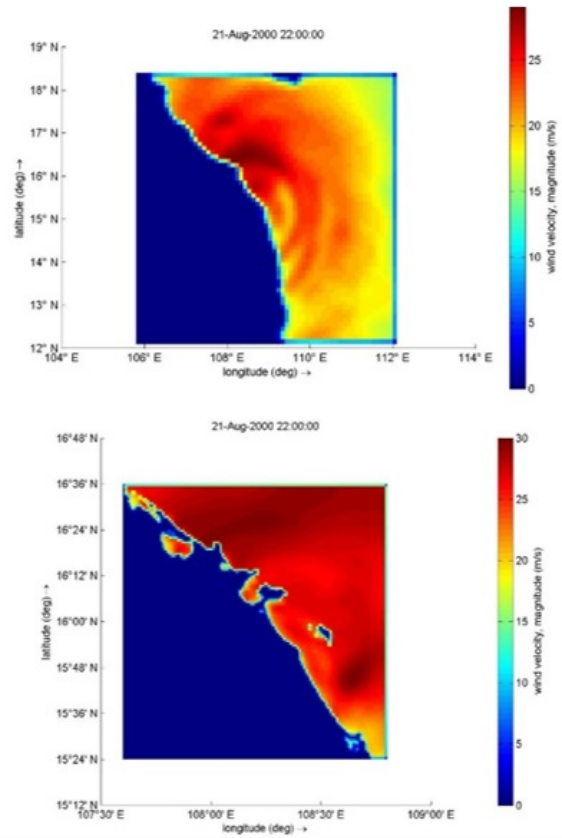
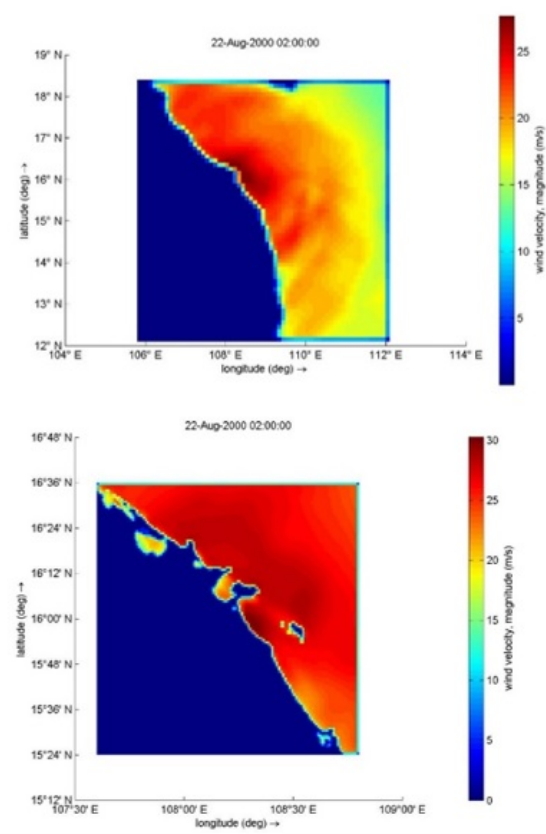

Figure 5: Wind speed during Typhoon Kaemi, 2000 (UTC)

6

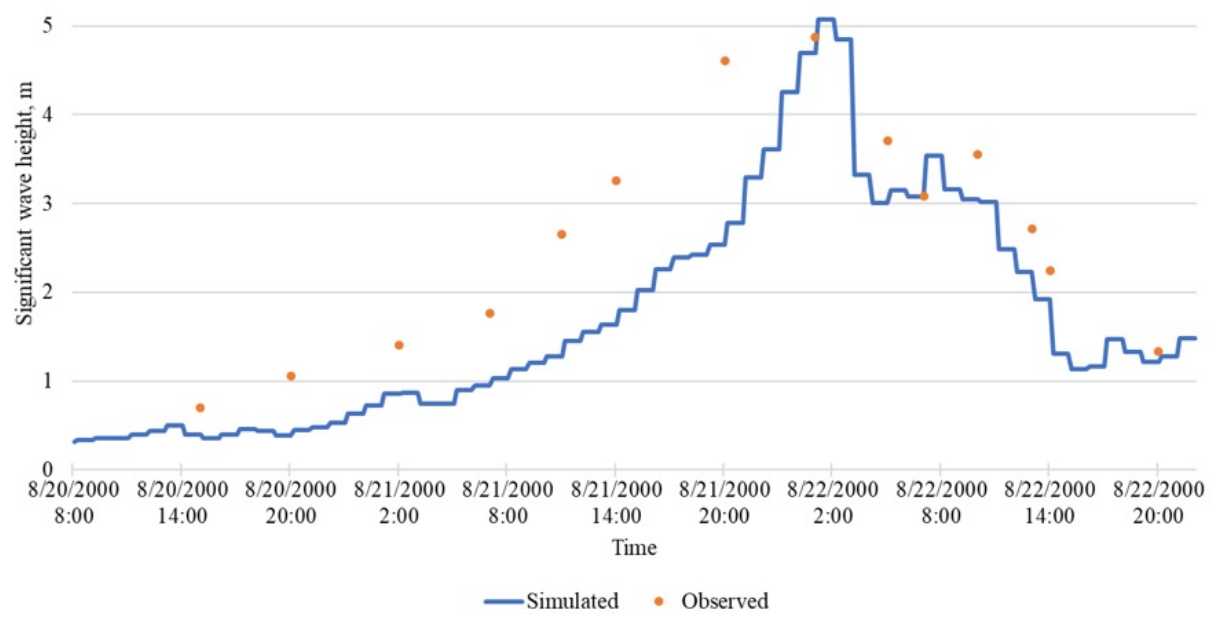

Figure 6: Reproduced and measured wave height at "Wave observation" during Typhoon Kaemi, 2000 (UTC) 
Xangsane. The observed water level from Son Tra gauged ${ }^{60}$ was used to calibrate the model results. In this paper, the author used the wind drag coefficient according to Nguyen Tho Sao, 2015 ${ }^{59}: C_{D}=0.00063$ with a wind speed of $1 \mathrm{~m} / \mathrm{s}$ and $\mathrm{C}_{D}=0.00723$ with a wind speed of $100 \mathrm{~m} / \mathrm{s}$. The other parameter Roughness is adjusted by referring to the publications that also focused on the similar interesting areas ${ }^{59-61}$, that range from 0.018-0.026. The default value of the Manning coefficient in Delft3D-FLOW is 0.015 . The comparison results of adjusting the value within the mentioned range show insignificant variation, thus the authors apply the value of 0.02 for the Manning coefficient as the majority of other authors used and also best fit with the observed data (Table 2). The comparison of the model results and measured data is shown in Figure 7. It shows that the coupled model could well simulate the water level (RMSE=0.42), especially during the landfall period - 1 day around the landfall time (RMSE=0.33), including the peak value (approximately $1.5 \mathrm{~m}$ surge), while it shows the limitation of the earlier and later period. However, the most threatening risk of the storm surge coming from the peak rising water level. In this aspect, the coupled models almost did that.

Compared to Northern and Central Vietnam, the frequency of typhoons in Southern Vietnam-which includes the Mekong Delta and other remote islands-is relatively low. As such, the risk of a typhoon disaster tends to be overlooked in this region; however, typhoons do occasionally make landfall in the southern part of Vietnam ${ }^{62}$.

Due to this reason, we chose Typhoon Durian (2006), which was considered a violent tropical typhoon to validate the accuracy of the models. For the case of Typhoon Durian, the central pressure went down to 940hPa during her first landfall period in the Philippines with a wind speed was up to 90 knots $(45 \mathrm{~m} / \mathrm{s})$ and cause severe damage at the islands. Fortunately, after crossing the South Chian Sea, Typhoon Durian weakened when it approached the Mekong Delta coastal zone, with the central pressure was $980 \mathrm{hPa}$ and 60 knots $(30 \mathrm{~m} / \mathrm{s})$ wind speed. Strong winds capsized several boats offshore Vietnam, and heavy rainfall from the typhoon destroyed many schools and houses. We also used a coupled models to investigate Typhoon Durian with the same input parameters as the case of Typhoon Xangsane, 2006. The measured data taken from the Vung Tau gauge was used to compare with the model output. The results in Figure 8 showed that the reproduced values well matched with the water level in terms of amplitude and phase.

\section{DISCUSSION}

In terms of high wave distribution caused by Typhoon Kaemi, according to Figure 9, the significant wave height in the offshore area outside Da Nang was more than $10 \mathrm{~m}$. This wave was hazardous for any fishing boat or ship, which still staying outside the shelter. As mentioned above, Typhoon Kaemi developed and propagated very quickly within 2 days. Thus it is necessary to have an early warning system to reduce the loss in such extreme weather events. According to Figure 10, the wave height when Typhoon Kaemi hit the land was around $5 \mathrm{~m}$, and the affected area (with significant wave height more than 2,0m) stretched from Thua Thien Hue to Quy Nhon, show the extensive impact. It is noticeable that Central Vietnam is famous for the beautiful sandy beaches. Hence, many densely populated areas are found close to the beaches with many buildings, houses, hotels, resorts, restaurants...serving for tourist industry located along the empty beach (without adequate protected structure). Due to this situation, the places within the affected areas are very vulnerable to the simulated wave height. To estimate the surge height (excluding the astronomic tide level) caused by Typhoon Xangsane (2006), the reproduced water level from the coupled hydrodynamic Deft3D-FLOW and WAVE model with and without considering the tide effect were plotted. The surge level was the difference between two results (Figure 11), it was around $0.53 \mathrm{~m}$. This abnormal rising water level probably caused flooding at some places in Da Nang. According to Figure 12, the rising water level along the coastline from Da Nang to Quang Nam ranged between 1.2 - $1.8 \mathrm{~m}$. A flooded situation was also recorded in Hoi An. The concave shape of the coastline at Da Nang and Hoi An probably amplified the water level, which made the situation more severe.

The well-reproduced water level during Typhoon Durian period in Figure 8 shows that the domain D1, which is used for the tide simulation, probably is large enough to include the effect of all tidal constituents. The observed data show the harmonic fluctuation, and there was almost no abnormal peak. Thus the water level mainly governs by the tidal level, which means the effect of the typhoon on water rising in this area was not significant. The track of Typhoon Durian that crossed along the coastline, not like typical typhoon track as propagating into the land, probably one of the reasons for this result. However, according to Figure 13, also due to the sliding track, the rising water level was the same along its paths, including in Ho Chi Minh City and also Long An, Tien Giang, Ben 
Table 2: The Manning coefficient calibration

\begin{tabular}{lllllll} 
Manning coefficient & 0.015 & 0.018 & 0.02 & 0.023 & 0.026 & Observed \\
$\begin{array}{l}\text { Peak water level at Son Tra gauge, } \\
\mathrm{m}\end{array}$ & 1.53038 & 1.52262 & 1.51689 & 1.50923 & 1.50217 & 1.51 \\
\hline
\end{tabular}

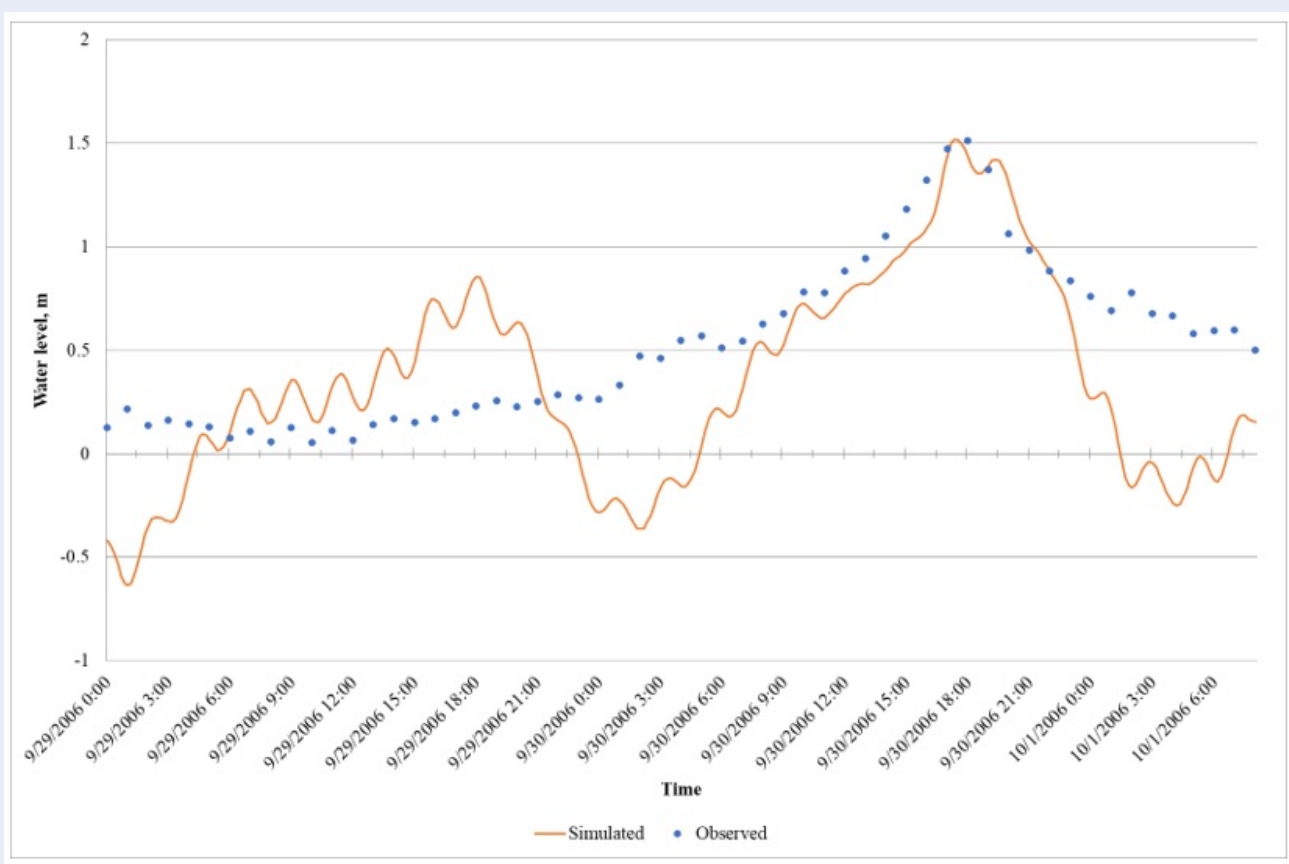

Figure 7: Water level at Son Tra Gauge station durring Typhoon Xangsane, 2006 (UTC)

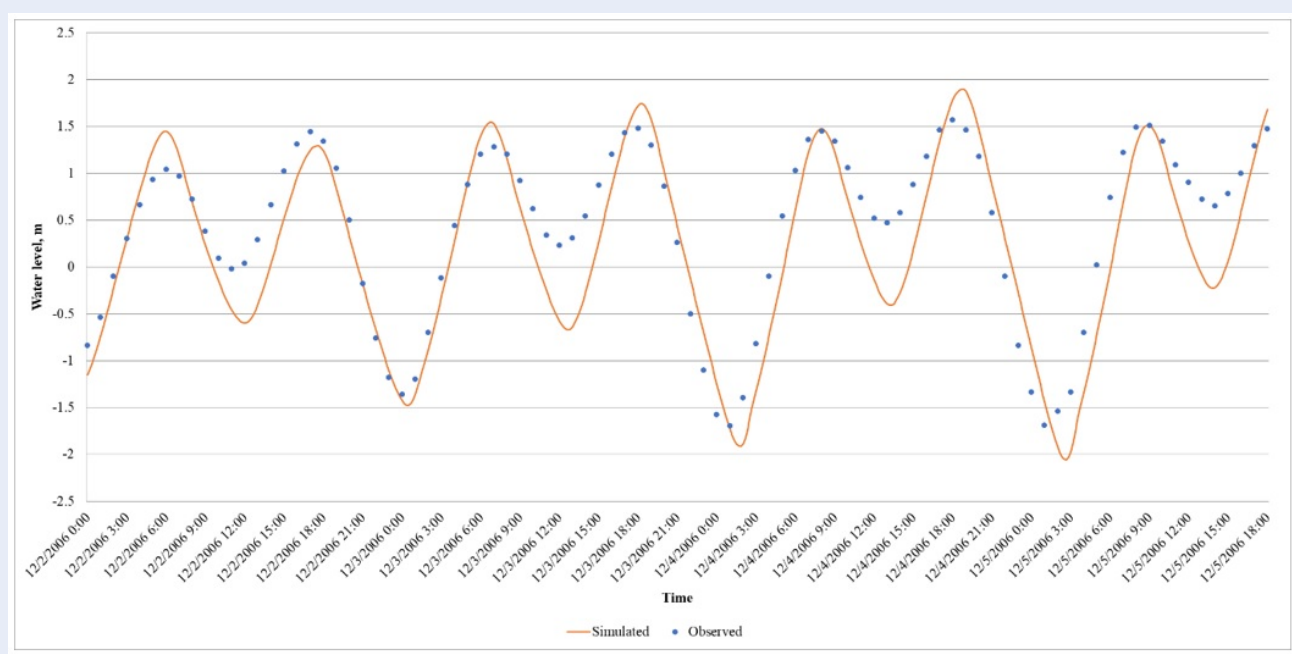

Figure 8: Water level at Vung Tau Gauge station during Typhoon Durian, 2006 (UTC) 
Tre, Tra Vinh... provinces, which was ranged from 1.2 to more than $1.4 \mathrm{~m}$. It is noticeable that storm surges can be considered to pose the greatest risk to low-lying coastal areas of the Mekong Delta, which is around $1 \mathrm{~m}$ above mean sea level. In contrast, fluvial and pluvial flood events appear to be more predominant in the upper part of the delta, close to the Cambodian bor$\operatorname{der}^{63}$.

\section{CONCLUSION}

Typhoon related disasters are the obvious risk for the Vietnam coast due to the high frequency of extreme weather every year. In this situation, numerical models used to forecast the physical impact, including storm surge and high wave, in order to mitigate the damage caused by those events, is necessary. The WRF model with modified schemes show its ability to reproduce the wind filed during the typhoon period, which fit well with the observed data. The coupled models Delft3D-FLOW and Delft3D-WAVE (SWAN) using meteorological input from WRF simulated the storm surge and high wave caused by typhoons, that underestimated the value before the typhoon made landfall. The limitation of the models come from the size of the domains and also the effect from other factors such as river discharge, swell... However, the results showed a good agreement with the measured data after the typhoon made landfall, especially in terms of the peak value, including peak water level and highest significant wave height, which mainly governed by the typhoon wind field. In other words, the suggested coupled models can able to use to investigate the impact of the typhoon induced disasters.

\section{ACKNOWLEDGEMENT}

The study was supported by The Youth Incubator for Science and Technology Programe, managed by Youth Development Science and Technology Center Ho Chi Minh Communist Youth Union and Department of Science and Technology of Ho Chi Minh City, the contract number is “ $36 / 2019 / \mathrm{HĐ-KHCN-VU"}$

\section{LIST OF ABBREVIATIONS USED}

WRF: Weather Research And Forecasting Model MONRE: Ministry Of Natural Resources And Environment

NCAR: National Center for Atmospheric

NCEP: National Centers for Environmental Prediction

ARW: Advanced Research WRF

NWP: Numerical Weather Prediction

ADCIRC: The ADvanced CIRCulation model
FVCOM: Finite Volume Community Ocean Model CH3D-SSMS: Curvilinear Hydrodynamic in 3D Storm Surge Modeling System

FD: Finite Difference

SLOSH: Sea, Lake, and Overland Surges from Hurricanes

WAM: Wave Modelling

SWAN: Simulating WAves Nearshore

\section{COMPLETING INTERESTS}

The author declares that there is no conflict of interest regarding the publication of this paper.

\section{AUTHOR'S CONTRIBUTIONS}

All the contents and the results from the numerical simulation of this article have been developed by the authors.

\section{REFERENCES}

1. CIRIA, CUR, and CEFMEF. Physical site conditions and data collection. In The Rock Manual. 2007;p. C683.

2. Fritz HM, Blount C, Sokoloski R, Singleton J, Fuggle A, McAdoo BG, Moore A, Grass C, Tate B. Hurricane Katrina storm surge distribution and field observations on the Mississippi Barrier Islands. Estuarine, Coastal and Shelf Science. 2007;74:12-20. Available from: https://doi.org/10.1016/j.ecss.2007.03.015.

3. Mikami T, Shibayama T, Takagi H, Matsumaru R, Esteban $M_{\text {, }}$ Thao ND, De Leon M, Valenzuela VP, Oyama T, Nakamura R, Kumagai K and Li S. Storm Surge Heights and Damage Caused by the 2013 Typhoon Haiyan along the Leyte Gulf Coast. Coastal Engineering Journal. 2016;58(1). Available from: https: //doi.org/10.1142/S0578563416400052.

4. NDRRMC. Effects of Typhoon "YOLANDA" (HAIYAN). SitRep. 2014;(106).

5. Takagi $\mathrm{H}$, Xiong $\mathrm{Y}$, Furukawa F. Track analysis and storm surge investigation of 2017 Typhoon Hato: were the warning signals issued in Macau and Hong Kong timed appropriately? Georisk. 2018;p. 297-307. Available from: https://doi.org/10. 1080/17499518.2018.1465573.

6. Bricker J, Takagi H, Mas E, Kure S, Adriano B, Yi C and Roeber V. Spatial variation of damage due to storm surge and waves during Typhoon Haiyan in the Philippines. Journal of Japan Society of Civil Engineers, Ser. B2 (Coastal Engineering). 2018;70(2). Available from: https://doi.org/10.2208/kaigan.70. I_231.

7. GTZ. Climate change and development in Vietnam: agriculture and adaptation for the Mekong Delta Region. Climate Protection Programme. 2003;p. 30.

8. Kleinen J. Historical perspectives on typhoons and tropical storms in the natural and socio-economic system of Nam Dinh (Vietnam). J. Asian Earth Sci. 2007;29:523531. Available from: https://doi.org/10.1016/j.jseaes.2006.05.012.

9. Ministry of Natural Resources and Environment of Vietnam (MONRE). Viet Nam Initial National Communication under the United Nations Framework Convention on Climate Change. 2003;Available from: http://unfccc.int/resource/docs/ natc/vnmnc01.pdf.

10. Ministry of Natural Resources and Environment of Vietnam (MONRE), Climate Change, Sea Level Rise Scenarios for Viet Nam. 2009;Available from: http://www.preventionweb. net/english/professional/publications/.

11. Truong VB, Nguyen NQ, Vu VN. Research on forecasting possibility of flooding occurring in coastal areas in Vietnam during typhoon, super typhoon. Journal of Water Resources Science and Technology. 2016;33-2016. 


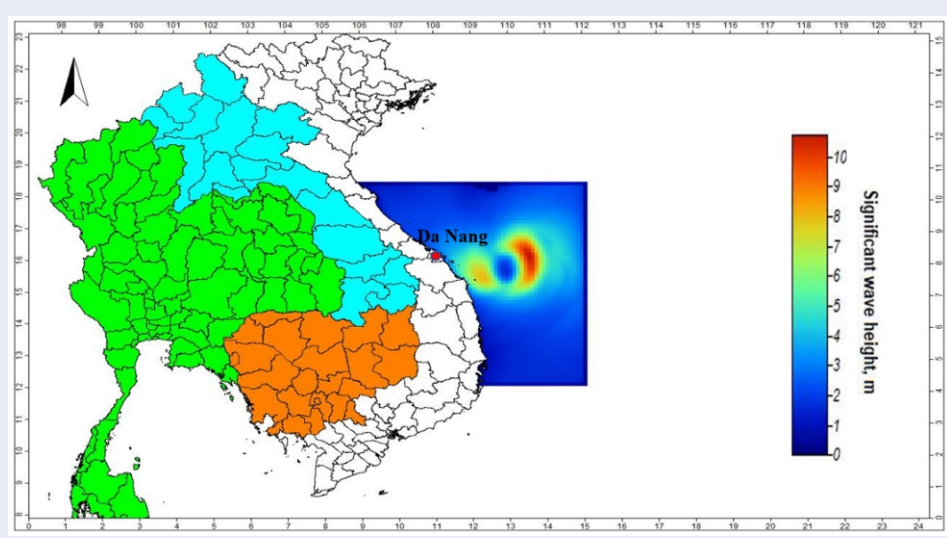

Figure 9: The offshore wave height distribution when Typhoon Kaemin, 2000 approaching Da Nang

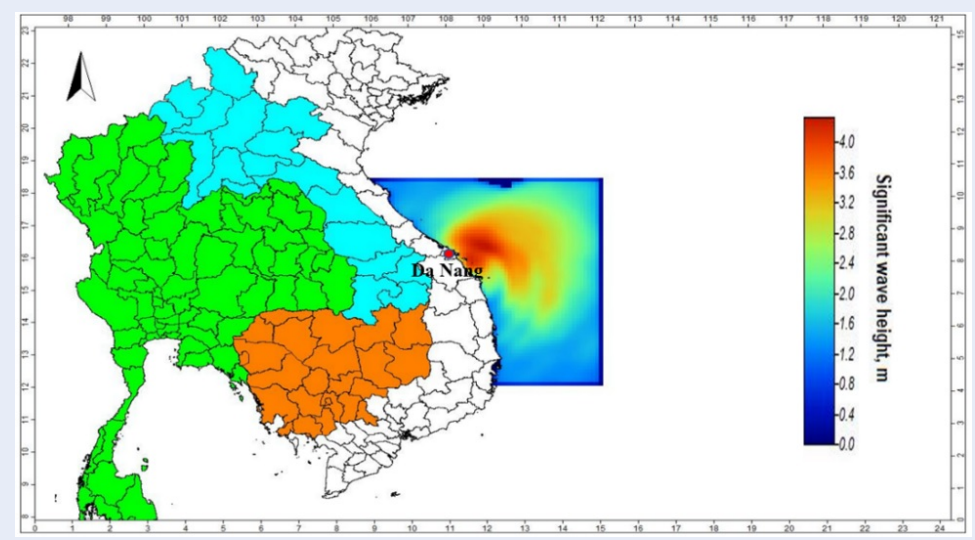

Figure 10: The wave height distribution when Typhoon Kaemin, 2000 made landfall at Da Nang

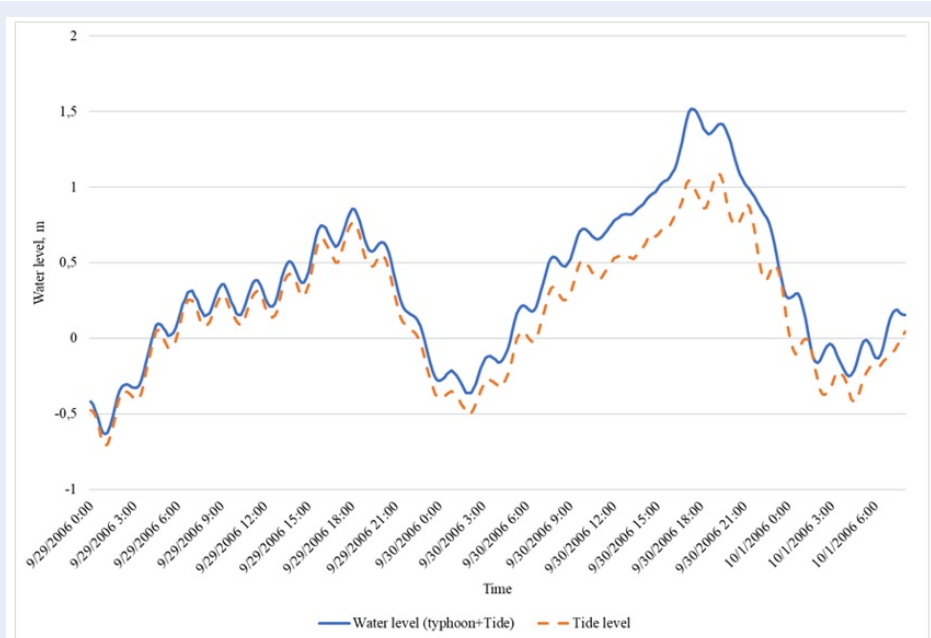

Figure 11: Surge level caused by typhoon Xangsane (2006) at Son Tra Gauge station (UTC) 


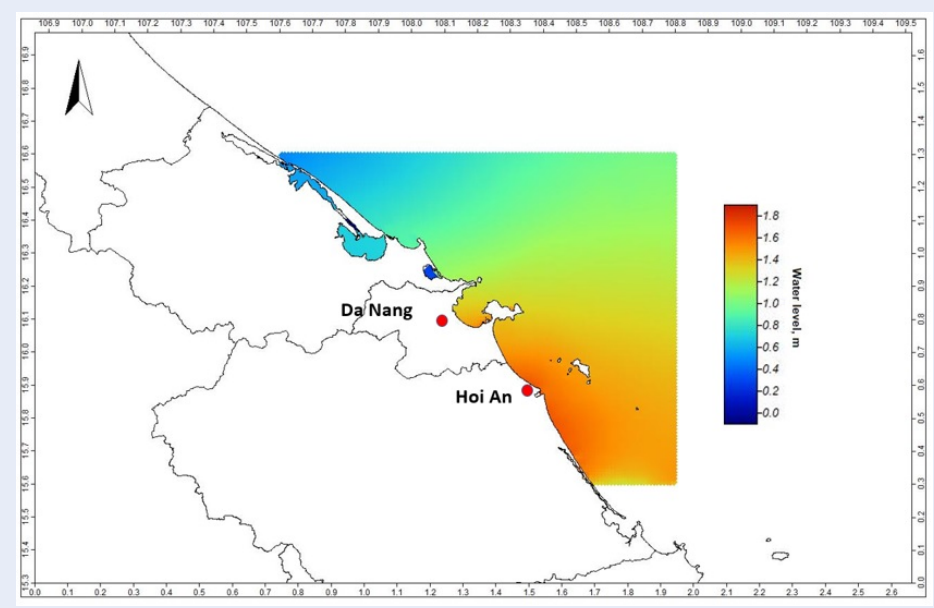

Figure 12: Water level during typhoon Xangsane (2006)

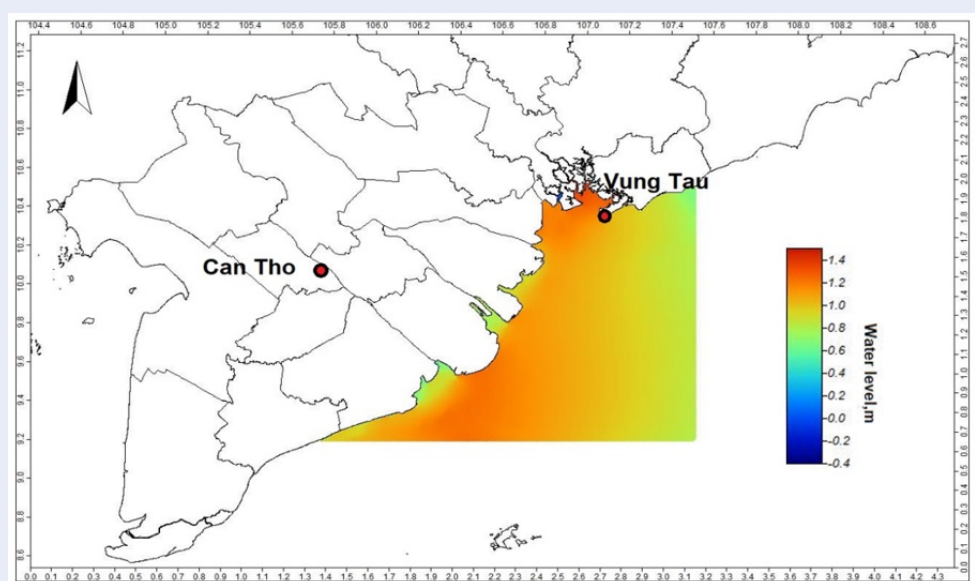

Figure 13: Rising water level distribution during Typhoon Durian period

12. Kim SY, Yasuda T, Mase H. Wave set-up in the storm surge along open coasts during Typhoon Anita. Coastal Engineering. 2010;57:631-642. Available from: https://doi.org/10.1016/ j.coastaleng.2010.02.004.

13. Islam MR, Takagi H. Statistical significance of tropical cyclone forward speed on storm surge generation: retrospective analysis of best track and tidal data in Japan. Georisk: Assessment and Management of Risk for Engineered Systems and Geohazards. 2020;Available from: https://doi.org/10.1080/17499518. 2020.1756345.

14. Mastenbroek C, Burgers G, Janssen P.A.E.M. The dynamical coupling of a wave model and a storm surge model through the atmospheric boundary layer. J. Phys. Oceanogr. 1993;23:1856-1866. Available from: https://doi.org/10.1175/ 1520-0485(1993)023<1856:TDCOAW>2.0.CO;2.

15. Zhang MY, Li YS. The dynamic coupling of a third-generation wave model and a 3D hydrodynamic model through boundary-layers. Cont. Shelf Res. 1997;17:1141-1170. Available from: https://doi.org/10.1016/S0278-4343(97)00010-1.

16. Xie L, Liu H, Peng M. The effect of wave-current interactions on the storm surge and inundation in Charleston Harbor during Hurricane Hugo 1989. Ocean Model. 2008:20:252-269. Available from: https://doi.org/10.1016/j.ocemod.2007.10.001.
17. Hoán VN. Phương pháp thống kê dự báo nước dâng và mực nước ven biển miền bắc Việt Nam khi bão tới, Luânn án Tiến sĩ, Hà Nội. 1988;

18. Ninh PV. The storm surge model. UNDP Project VIE/87/020 Hanoi. 1992;.

19. Thắng NV. Xây dựng sơ đồ dự tính dư báo nước dâng ở vùng ven biển Hải Phòng, Luận án tiến sĩ địa lí - địa chất, Viện Khí tượng Thủy văn, Hà Nội. 1999;.

20. Thông BX. Mô hình dự báo nước dâng do bão sử dụng hệ lưới lồng áp dụng cho các lưu vực nhỏ. Khí tượng - Thủy văn vùng biển Việt Nam. NXB Thống kê, Hà Nội. 2000;.

21. Hiển NX, Thục T, Đinh Văn Ưu. Nghiên cứu, tính toán nước dâng tổng cộng trong bão cho khu vực ven biển thành phố Hải Phòng. Tạp chí Khoa học Đại học Quốc gia Hà Nội, Khoa hoc Tự nhiên và Công nghê.. 2012;28(3S):63-70.

22. Tasnim KM, Shibayama T, Esteban M, Takagi H, Ohira K, Nakamura R. Field observation and numerical simulation of past and future storm surges in the Bay of Bengal: case study of cyclone Nargis. Natural Hazards. 2014;75(2):1619-1647. Available from: https://doi.org/10.1007/s11069-014-1387-x.

23. Skamarock WC, Klemp JB. A time-split nonhydrostatic atmospheric model for weather research and forecasting applica- 
tions. J Comput Phys. 2008;227(7):3465-3485. Available from: https://doi.org/10.1016/j.jcp.2007.01.037.

24. Skamarock WC, Klemp JB, Dudhia J, Gill DO, Barker DM, Duda MG, Huang XY, Wang W, Power JG. A Description of the Advanced Research WRF Version 3. NCAR TECHNICAL NOTE. 2008;

25. Mori N, Kato M, Kim S, Mase H, Shibutani Y, Takemi T, Tsuboki K, Yasuda T. Local amplification of storm surge by Super Typhoon Haiyan in Leyte Gulf. Geophysical Research Letters. 2014;41(14):5106-5113. PMID: 25821268. Available from: https://doi.org/10.1002/2014GL060689.

26. Hendricks EA, Jin Yi, Moskaitis JR, et al.. Numerical simulations of Typhoon Morakot (2009) using a multiply nested tropical cyclone prediction model. Weather and Forecasting. 2016;31(2):627-645. Available from: https://doi.org/10.1175/ WAF-D-15-0016.1.

27. Jun S, Kang NY, Lee $W$, et al.. An alternative multi-model ensemble forecast for tropical cyclone tracks in the western North Pacific. Atmosphere. 2017;8(9):174. Available from: https://doi.org/10.3390/atmos8090174.

28. Xingliang $G$, Wei Z. The use of a spectral nudging technique to determine the impact of environmental factors on the track of typhoon megi (2010). Atmosphere. 2017;8(12):257. Available from: https://doi.org/10.3390/atmos8120257.

29. Weng $\mathrm{CH}, \mathrm{Hsu} \mathrm{HH}$. Intraseasonal oscillation enhancing $\mathrm{C} 5$ typhoon occurrence over the tropical western North Pacific. Geophysical Research Letters. 2017;44(7):3339-3345. Available from: https://doi.org/10.1002/2017GL072743.

30. Funing $L$, Jinbao $S, X i a ~ L$. A preliminary evaluation of the necessity of using a cumulus parameterization scheme in highresolution simulations of Typhoon Haiyan (2013). Natural Hazards. 2018;92(2):647-671. Available from: https://doi.org/10. 1007/s11069-018-3218-y.

31. Jelesnianski CP, Taylor AD. A preliminary view of storm surges before and after storm modification. NOAA Technical Memorandum. ERL, WMPO-3. 1973;p. 33.

32. Arakawa A, Lamb VR. Computational design of the basic dynamical processes of the UCLA general circulation model. In Methods of Computational Physics. 1977; Chang, J., Ed. Academic Press: New York, NY, USA;p. 173-265. Available from: https://doi.org/10.1016/B978-0-12-460817-7.50009-4.

33. The WAMDI Group. The WAM Model-A third generation ocean wave prediction model. J. Phys. Oceanogr. 1988;18:1775-1810. Available from: https://doi.org/10.1175/ 1520-0485(1988)018<1775:TWMTGO>2.0.CO;2.

34. Tolman HL. The Numerical Model WAVEWATCH: A Third Generation Model for the Hindcasting of Wind Waves on Tides in Shelf Seas. Communications on Hydraulic and Geotechnical Engineering, Delft University of Technology. 1989;89:72-,

35. DHI. MIKE 21 SW, User manual, DHI Water and Environment, Denmark. 2011:

36. Booij N, Ris RC, Holthuijsen LH. A third-generation wave model for coastal regions 1. Model description and validation. J. Geophysical Res. 1999;104(4):7649-7666. Available from: https: //doi.org/10.1029/98JC02622.

37. Chawla A. Global Bathymetry Validation Study. MMAB Contribution. 2007;(253)

38. Strauss D, Mirferendes, $H$, Tomlinson R. Comparison of two wave models for Gold Coast, Australia. J. Coastal Research. SI 50 (Proceedings of the 9th International Coastal Symposium). 2007;p. $312-316$.

39. Remya PG, Raj Kumar, Sujit Basu, Abhijit Sarkar. Wave hindcast experiments in the Indian Ocean using MIKE 21 SW model. J. Earth Syst. Sci. 2012;v(2):385-392. Available from: https://doi. org/10.1007/s12040-012-0169-7.

40. Holthuijsen LH, Booij N, Bertotti L. The Propagation of Wind Errors Through Ocean Wave Hindcasts. J. Offshore Mechanics and Artic Engg. 1996;118(3):184-189. Available from: https: //doi.org/10.1115/1.2828832.

41. Moeini MH, Etemad-Shahidi A, Chegini V, Rahmani I. Wave data assimilation using a hybrid approach in the Persian Gulf. Ocean Dynamics. 2012;62(5):785-797. Available from: https: //doi.org/10.1007/s10236-012-0529-5.

42. Longuet-Higgins MS, Stewart RW. Changes in the form of short gravity waves on long waves and tidal currents. J. Fluid Mech. 1960;8:565-583. Available from: https://doi.org/10. 1017/S0022112060000803.

43. Longuet-Higgins MS, Stewart RW. Radiation stress and mass transport in gravity waves with application to surf beat. J. Fluid Mech. 1962;13:481-504. Available from: https://doi.org/ 10.1017/S0022112062000877.

44. Funakoshi Y, Hagen SC, Bacopoulos P. Coupling of hydrodynamic and wave models: case study for Hurricane Floyd (1999) Hindcast. J. Waterw. Port Coast. Ocean Eng. 2008;Available from: https://doi.org/10.1061/(ASCE)0733-950X(2008) 134:6(321).

45. Chen $\mathrm{Q}$, Wang $\mathrm{L}$, Zhao H. An integrated surge and wave modeling system for Northern Gulf of Mexico: simulations for Hurricanes Katrina and Ivan. Proc. Int. Conf. Coast. Eng., ASCE. 2008;p. 1072-1084.

46. Islam MR, Takagi H. Typhoon parameter sensitivity of storm surge in the semienclosed Tokyo Bay. Frontiers of Earth Science. 2020;Available from: https://doi.org/10.1007/s11707020-0817-1.

47. Takagi H, Pratama MB, Kurobe S, Esteban M, Aránguiz R, Ke B Analysis of generation and arrival time of landslide tsunami to Palu City due to the 2018 Sulawesi earthquake. Landslides. 2019;16(5):983-991. Available from: https://doi.org/10.1007/ s10346-019-01166-y.

48. Whitham G. Linear and nonlinear waves. Wiley, New York. 1974;.

49. Mei C. The applied dynamics of ocean surface waves. Wiley, New York. 1983;Available from: https://doi.org/10.1016/00298018(84)90033-7.

50. Dingemans MW. Water Wave Propagation over Uneven Bottoms, Vol. 1 and 2. Advanced Series on Ocean Engineering 1997; Vol. 13. World Scientific, London;Available from: https: //doi.org/10.1142/1241-part1.

51. Paulson CA. The mathematical representation of wind speed and temperature profiles in the unstable atmospheric surface layer. J Appl Meteorol. 1970;9:857-861. Available from: https://doi.org/10.1175/1520-0450(1970)009<0857: TMROWS $>2.0$. CO; 2 .

52. Dyer AJ, Hicks BB. Flux-gradient relationships in the constant flux layer. Q J R Meteorol Soc. 1970;96:715-721. Available from: https://doi.org/10.1002/qj.49709641012.

53. Webb EK. Profile relationships: the log-linear range, and extension to strong stability. Q J R Meteorol Soc. 1970;96:67-90. Available from: https://doi.org/10.1002/qj.49709640708.

54. Beljaars ACM. The parameterization of surface fluxes in largescale models under free 530 convection. Q J R Meteorol Soc. 1994;121:255-270. Available from: https://doi.org/10.1002/qj. 49712152203.

55. Zhang DL, Anthes RA. A high-resolution model of the planetary boundary layer-sensitivity tests and comparisons with SESAME-79 data. J Appl Meteorol. 1982;21:1594-1609. Available from: https://doi.org/10.1175/1520-0450(1982)021<1594: AHRMOT>2.0.CO;2.

56. Hong SY, JOJ Lim. The WRF single-moment 6-class microphysics scheme (WSM6). J. Korean Meteor. Soc. 2006;42(2):129-151.

57. Tewari M, Chen F, Wang W, Dudhia J, LeMone MA, Mitchell K, Ek M, Gayno G, Wegiel J, Cuenca RH. Implementation and verification of the unified NOAH land surface 677 model in the WRF model. In: 678 20th conference on weather analysis and forecasting/16th conference on numerical weather prediction. 2004;(679):11-15.

58. Hong SY, Noh Y, Dudhia J. A new vertical diffusion package with an explicit treatment of entrainment processes. Mon Weather Rev. 2006;134:2318-2341. Available from: https:// doi.org/10.1175/MWR3199.1.

59. Sao NT. Storm surge predictions for Vietnam coast by Delft3D model using results from RAMS model. Journal of Water Re- 
sources and Environmental Engineering. 2008;(23).

60. Đăng VH, Thủy NB, Chiến DDD, Kim S. Nghiên cứu đánh giá định lượng các thành phần nước dâng trong bão bằng mô hình số trị. Tạp chí Khoa học và Công nghệ Biển. 2017;17(2):132-138. Available from: 2017.

61. Tran NN, Nagai K, Kubota H, Hue NN, Quang DX. Statistical characteristics of unusual waves observed at Danang, Vietnam. Asian and Pacific Coasts 2003: Proceedings of the 2nd International Conference;.
62. Anh LT, Takagi H, Thao ND, Esteban M. Investigation of Awareness of Typhoon and Storm Surge in the Mekong Delta - Recollection of 1997 Typhoon Linda. Journal of Japan Society of Civil Engineers, Ser. B3 (Ocean Engineering). 2017;73(2):168173. Available from: https://doi.org/10.2208/jscejoe.73.I_168.

63. Takagi H, Tran TV, Nguyen DT, Esteban M. Ocean Tides and the Influence of Sea-Level Rise on Floods in Urban Areas of the Mekong Delta. J. Flood Risk Management. 2014;8(4):292-300. Available from: https://doi.org/10.1111/jfr3.12094. 


\title{
Nghiên cứu hiện tượng nước dâng do bão và sóng tại Việt Nam bằng mô hình kết hợp Delft3d-FLOW và WAVE sử dụng trường gió mô phỏng từ mô hình dự báo khí tượng (WRF)
}

\author{
Lê Tuấn Anh ${ }^{*}$, Đặng Hoàng Anh, Mai Thị Yến Linh, Nguyễn Danh Thảo
}

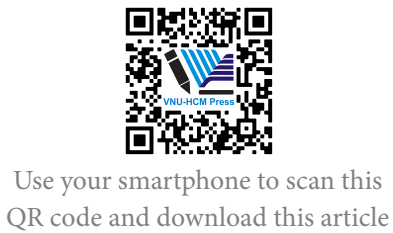

Bộ môn Cảng - Công trình biển, Khoa Kỹ thuật Xây dựng, Trường Đại học Bách Khoa, ĐHQG-HCM, Việt Nam

Liên hệ

Lê Tuấn Anh, Bộ môn Cảng - Công trình biển, Khoa Kỹ thuật Xây dựng, Trường Đại học Bách Khoa, ĐHQG-HCM, Việt Nam

Email: tuananh131188@hcmut.edu.vn

Lịch sử

- Ngày nhận: 30-9-2020

- Ngày chấp nhận: 07-01-2021

- Ngày đăng: 15-02-2021

DOI : 10.32508/stdjet.v4i1.774

\section{Check for updates}

\section{Bản quyền}

๑ ĐHQG Tp.HCM. Đây là bài báo công bố mở được phát hành theo các điều khoản của the Creative Commons Attribution 4.0 International license.

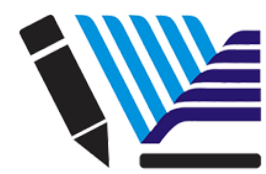

VNU-HCM Press

\section{TÓM TÁ́T}

Giới thiệu: Các hiện tượng thiên tai do bão gây ra bao gồm nước dâng do bão và sóng cao là những mối đe dọa đối với các vùng ven biển Việt Nam. Chính vì vậy, nhiều nhà khoa học đã tập trung nghiên cứu về vấn đề này từ lâu với nhiều cách tiếp cận khác nhau, từ thống kê cho đến sử dụng mô hình số trị. Nghiên cứu này đề xuất sử dụng mô hình kết hợp Delft3D-FLOW và WAVE sử dụng trường gió mô phỏng từ mô hình Dự báo khí tượng (WRF) để nghiên cứu các hiện tượng thiên tai do bão gây ra tại Việt Nam. Phương pháp nghiên cứu: mô hình WRF được vận hành sử dụng nhiêu lưới tính toán với các độ phân giải khác nhau đồng thời và có xét đến tương tác giữa các lưới này với nhau (lưới lồng) để mô phỏng lại trường gió trong các cơn bão. Mô hình Delft3D-FLOW được kết hợp với mô hình Delft3D-WAVE (SWAN) thông qua cơ chế tương tác động, có nghĩa là mô hình FLOW sẽ xét đến ứng suất tán xạ do sóng mà mô hình WAVE tính toán. Đồng thời mực nước tính toán từ mô hình FLOW bao gồm cả mực nước dâng sẽ được cập nhật và sư dụng bởi mô hình WAVE. Cả hai mô hình Delft3D-FLOW và Delft3D-WAVE đêu sử dụng trường gió mô phỏng từ mô hình WRF. Mực nước dâng tổng cộng sẽ là tổng hợp của mực nước dâng do bão, mực nước dâng do sóng và thủy triều. Kết quả: Trường hợp cơn bão Kaemi, 2000 được sử dụng để kiểm định trường gió và chiếu cao sóng mô phỏng. Quá trình hiệu chỉnh mô hình nước dâng do bão dựa trên dữ liệu mực nước thực đo trong cơn bão Xangsane (2006), trong khi trường hợp cơn bão Durian (2006) được dùng cho mục đích kiểm định mô hình. Quá trình so sánh cho thấy sự tương đồng cao giữa kết quả mô phỏng và kết quả thực đo, đặc biệt là các giá trị mực nước cực trị và chiều cao sóng cực đại, các giá trị này chủ yếu bị chi phối bởi trường gió bão. Kết quả mô phỏng chỉ ra rằng, dọc theo đường đi của bão Durian, mực nước dâng đạt giá trị $1.2-1.4 \mathrm{~m}$, các chiêu cao mực nước này có thể được xem là có thể gây tổn thương cho những vùng ven biển với cao độ mặt đất thấp tại Đồng bằng sông Cửu Long. Kết luận: Mô hình kết hợp được đề xuất có khả năng ứng dụng trong việc nghiên cứu các hiện tượng thiên tai do bão gây ra tại Việt Nam. Từ khoá: bão, nước dâng do bão, sóng gió, Việt Nam, WRF, Delft3D
Trích dẫn bài báo này: Anh LT, Anh D H, Linh MTY, Thảo N D. Nghiên cứu hiện tượng nước dâng do bão và sóng tại Việt Nam bằng mô hình kết hợp Delft3d-FLOW và WAVE sử dụng trường gió mô phỏng từ mô hình dự báo khí tượng (WRF). Sci. Tech. Dev. J. - Eng. Tech.; 4(1):645-662. 